\title{
The Impacts of COVID-19 on Indonesian Language Terminology
}

\author{
Dewi Kusumaningsih* \\ University of Veteran Bangun Nusantara \\ Dewikusumaningsih71@gmail.com \\ Hanisah Hanafi \\ State University of Gorontalo \\ Hanisahhanafi65@gmail.com
}

\author{
Wilda Elsiana Ningrum \\ University of Veteran Bangun Nusantara \\ Wildaelsiana007.we@gmail.com \\ Dian Eka Candra Wardhana \\ University of Bengkulu \\ Dec.wardhana@unib.ac.id
}

\author{
Satria Agung Wibawa \\ University of Veteran Bangun Nusantara \\ sagungwibawa@gmail.com
}

\begin{abstract}
This study aimed to explore the emergence of certain terms in Indonesian Language terminology, as the impact of the COVID-19 pandemic. Various lingual formswere found in words, acronyms, and phrases. Several conventional terms were also revived through an etymological process. The data source derived from the utilization of Indonesian Language in various news coverages from electronic mass media and social media (Instagram and Facebook) related to the COVID-19. Meanwhile, the data collecting techniques featured listening and documentation. The analysis utilized the element-chunking technique as well as the expansion of morphological and syntactical forms to determine the whole meanings of certainterms. The findings pointed out the introduction of new terms, re-introduction of conventional terms, changes in referents, as well as certain terms in the English Language which are syntactically interfered with within the Indonesian Language. The results of the study were expected to provide meaningful inputs for the Indonesian Language communities related to the language dynamics based on the current era.
\end{abstract}

Keywords: COVID-19, impact, term, pandemic

\section{INTRODUCTION}

Since the implementation of health protocols regarding the COVID-19 pandemic in Indonesia, mass media have been dominated by the updates of the crisis. The condition has significantly added the function of the media as the main source of references related to the COVID-19 [1], [2]. Therefore, the communities are convinced with all the news related to the outbreak [3], despite a large possibility of hoaxes. As an impact, those media have been penetrated withvarious terms that refer to the COVID-19 context. The phenomenon has emerged a significant number of new terms and revived some old terms in various forms, such asacronyms, and led to the improvements in Indonesian morphological and syntactic processes. Such terminological development aims to stimulate the understanding among the Indonesian Language speakers [4].

Based on the process of creation, the government has appeared as the main source of those specific terms related to the COVID-19. In fact of the etymological process, those terms were created by several parties, such as Language and Book Development Agency, academicians, researchers, journalists, as well as the communities and their local wisdom. However, the government has successfully affirmed its stance as the most dominant party, while the society is insisted to consume all emerging terms in all news coverage about the COVID-19. Nowadays, our people have familiarized themselves with those terms through theindependent constructionof meanings. This study was targeted to discuss the emergence of various terms in the Indonesian Language regarding the COVID-19 context based on the morphological and semantic perspectives. The results of the study were expected to facilitate the communities in grasping the understanding related to the new terms that emerged during the COVID-19 pandemic issue.

Some relevant studies regarding the COVID-19 issue have been exposed by [2], [5]-[8] through various contexts, such as health, religion, communication, national defense, and education. However, the number ofstudies related to the COVID-19 based on the Indonesian Language etymology is limitedly available only on online mass media [9].

A morphological process is a means of changing root to adjust its meaning to fit its syntactic and communicational context. The Indonesian Language has three kinds of morphological processes, including affixation, reduplication, and composition. 
Affixation includes all word-formation processes through the addition of affixes, ranging from prefixes, infixes, suffixes, and confixes. For instance, pemikir (thinker) derives from pikir (think) as the root. All affixed words are the results of the affixation process. Meanwhile, reduplication is a repetitive process of repeating the roots, such as the repetition of gedung-gedung (buildings) that derives from gedung (building). In contrast, ketidakadilan (injustice) can be picked up as one of the examples of a word-forming phrase that derives from an adjective phrase tidak adil (unjust). Meanwhile, the composition is the word-formation process by merging two roots into a new form to produce new meaning, such as dokter corona (corona doctor).

Lexical meaning is generally less fixed unless included in a certain sentence with a particular context [10]. In contrast, a contextual meaning (situational meaning) appears as a result of the relationship between utterances and situations that cover the time, space, and environment.

\section{METHOD}

This study presented a qualitative model with textual analysis. The data source derived from the discourse of mass media, including television broadcasts and social media (Instagram and Facebook) regarding the COVID-19 context. The data collection techniques consisted of listening and documentation. The listening was adopted to collect the data from television broadcasts through a note-taking activity. Meanwhile, the documentation was implemented through data screenshotting and transcription. The processes were meticulously performed to prepare sufficient data for analysis. The primary data consisted of all language units in the forms of words (roots, affixed words, repetitive words, and compound words) and phrases with the context of COVID-19. The analysis involved the direct element-chunking technique, in addition to theexpansion of morphological and syntactical forms to explore the whole meanings of certain terms based on the current context[11], [12].

\section{RESULT AND DISCUSSION}

The current crisis of the COVID-19 pandemic has encouragedvarious changes in Indonesian Language terminology, especially in its morphological forms. The emergence of the terms related to the COVID-19 context was quickly disseminated by the government, in which its process was performed without official inauguration by the technical procedures of the term creation. The pandemic appeared as a turmoil since March 2020 and globally contributed to a massive implication in various sectors. As the main party that should deal with the COVID-19 management, the government has appeared as the dominant role model that introduced several terms regarding the COVID-19 through the implementation of preventive regulations for all the stakeholders and communities.

Since then, our communities have now been familiar with some specific terms that they learned from news broadcasts on television and social media. The terms consisted of new terms as well as conventional terms, which are revived due to the continuous utilization in daily communication. Most of the terms related to the COVID-19 context appeared in the forms of words and acronyms. The elements of the words consist of roots (kata dasar$\mathrm{KD}$ ), affixes (kata imbuhan - KIm), repetitive words (kata ulang - KU), and compound words (kata majemuk-KM). The findings are explained with the following details:

\section{New Terms}

The newly observed terms are Corona and COVID-19 (the name of the virus that causes the current pandemic). COVID-19 derives from the acronym CO- (Corona), -VI- (virus), - $D$ (disease), and-19(the year of the pandemic emergence in 2019). Contextually, COVID-19 refers to the disease, which is caused by the Coronavirus. Both terms have eventually produced several derivatives within the context of COVID-19. The utilization of those terms is commonly perceived as a unity. Corona hasproduced more derivatives.

Another term, such as reaktif (reactive) refers to a condition that indicates the COVID-19 symptoms. It is a borrowing term from Chemistry, which nowadays has been widely used by the government and journalists in reporting the COVID-19 news. Its context aims to warn the communities of the COVID-19 infection, as part of an education effort to impose the health protocols.

Several new terms have also appeared in the forms of compound words in the Indonesian Language. The compound words indeed refer to Corona as the core meaning. Table 1 presents some terms within the context of COVID-19 in the forms of compound words. The above compound words have been increasingly utilized by the communities based on the current context of atmosphere, time, socio-culture, and locationin a transparent manner. Briefly, the creation of compound words related to the Corona can appear more in the future. Let's see.

\section{The revival of Conventional Terms}

Many conventional terms in the Indonesian Language have been re-introduced in a broader context, especially during the current COVID-19 pandemic. The utilization of those terms creates awareness about the COVID-19 management efforts made by the government to the communities. For instance, the term krusial (crucial) refers to an urgent condition, as part of a problem-solving attempt. Regarding the context, a reader who finds 
the word will certainly grow a perception to be alerted of the COVID-19 risk.

\section{Borrowing Terms}

Many borrowing terms related to the COVID-19, especially from the English Language are highly acceptable in Indonesia, such as physical distancing. It is a newly-consumed term thatrefers to the government's policy in appealing the communities to keep a safe physical distance, thus they can suppress the probability of infection. Physical distancing is considered more acceptable in Indonesian communities compared to its local translation jaga jarak.

\section{Initialism (Word-shortening of the initial forms)}

The acronym refers to the process of shortening the initial forms of words just (initialism). It is categorized as a morphological process, abbreviation [13], [14]. The increasingly dynamic and fast living conditions of the communities has led to the quick utilization of a certain language, such as the shortening particular terms. This process aims to foster the memorization capability of the creators and users of the language.The shortening effort can be in the form of initialism, for instance, PSBB (Pembatasan Sosial Berskala Besar), which means Large-Scale Social Restrictions in English. The term is utilized by the government to impose COVID-19

Table 1. Newly Compound Words Regarding the COVID-19

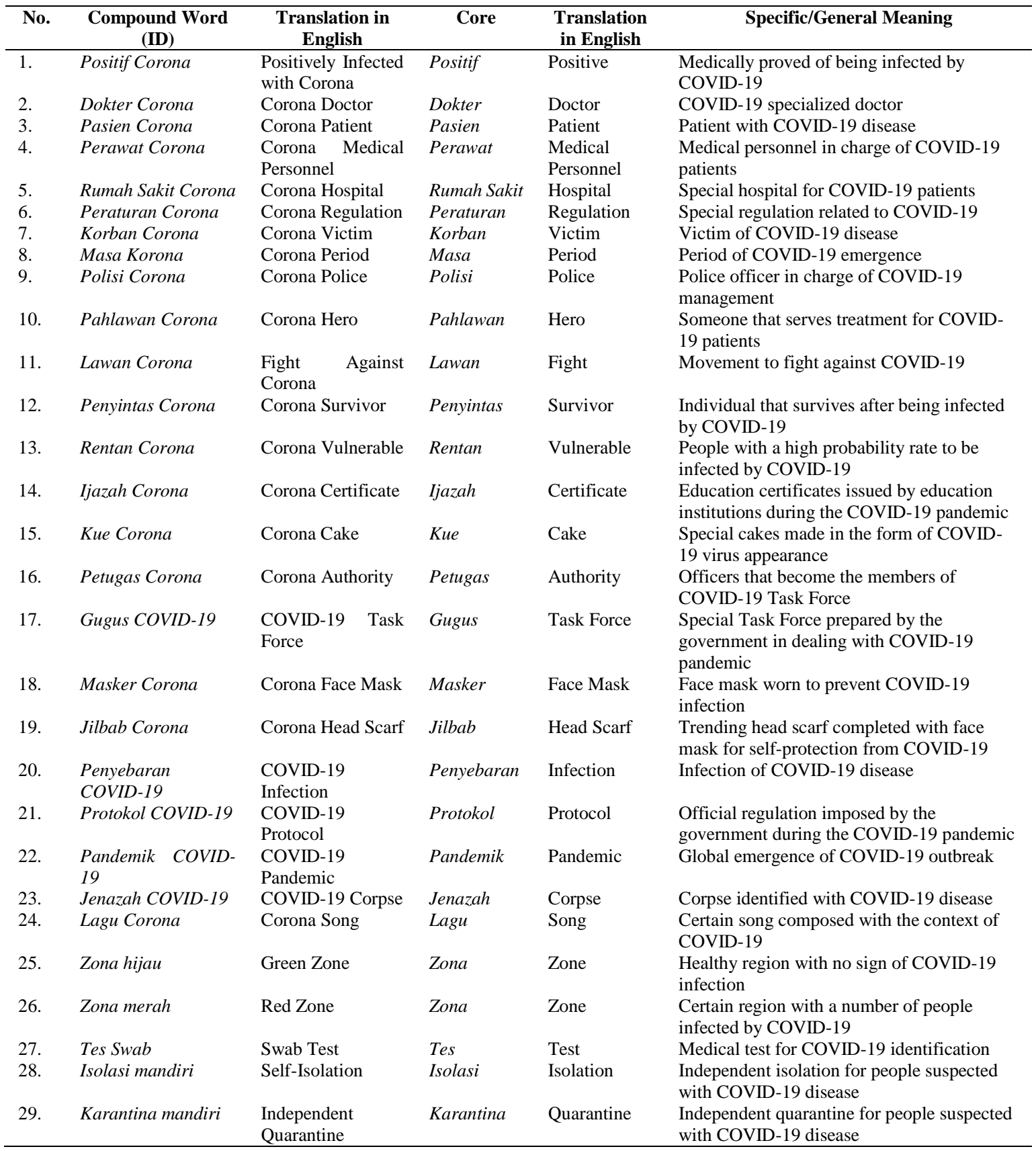


health protocols to the public. In particular, it refers to the restriction to some certain public activities in particular regions, which are suspected as the red zone of COVID-19 infection. Many acronyms that have appeared amid the current COVID-19 outbreak are described in Table 4.

Table 2. Revived Conventional Terms

\begin{tabular}{|c|c|c|c|c|}
\hline No & $\begin{array}{c}\text { Conventional } \\
\text { Term }\end{array}$ & $\begin{array}{c}\text { Translation in } \\
\text { English }\end{array}$ & $\begin{array}{l}\text { Lexical Meaning Based on The Great } \\
\text { Indonesian Dictionary (KBBI) }\end{array}$ & $\begin{array}{l}\text { Meaning Expansion Regarding } \\
\text { COVID-19 Context }\end{array}$ \\
\hline 1. & Dievaluasi & Be evaluated & Evaluasi/eva $\cdot l u \cdot a \cdot s i / / e ́ v a l u a s i / n$ penilaian/dinilai & $\begin{array}{l}\text { Implementation of all regulations } \\
\text { and policies }\end{array}$ \\
\hline 2. & Implementasi & Implementation & $\begin{array}{l}\text { Implementasi/im·ple } \cdot \text { men } \cdot \text { ta } \cdot \text { si//impleméntasi/ n pel } \\
\text { aksanaan; penerapan: }\end{array}$ & Imposing all prevailing regulations \\
\hline 3. & Imbauan & Appeal & $\begin{array}{l}\text { Imbauan/im.bau.an/ n panggilan; permintaan } \\
\text { (seruan); ajakan. }\end{array}$ & $\begin{array}{l}\text { Persuasion to comply with the } \\
\text { prevailing policies }\end{array}$ \\
\hline 4. & Pandemi & Pandemic & $\begin{array}{l}\text { Pandemi/pan } \cdot \text { de } \cdot \text { mi//pandémi/ } n \text { wabah yang } \\
\text { berjangkit serempak di mana-mana, meliputi } \\
\text { daerah geografi yang luas. }\end{array}$ & $\begin{array}{l}\text { Harmful epidemic which should be } \\
\text { carefully mitigated }\end{array}$ \\
\hline 5 . & Protokol & Protocol & $\begin{array}{l}\text { Protokol/pro.to } \cdot \text { kol } \\
\text { tata cara (upacara dan sebagainya) yang secara } \\
\text { internasional berlaku dalam hubungan diplomatik }\end{array}$ & $\begin{array}{l}\text { All social elements must comply } \\
\text { with the COVID-19 protocols }\end{array}$ \\
\hline 8. & Penyekatan & Insulation & $\begin{array}{l}\text { Penyekatan/pe } \cdot \text { nye } \cdot \text { kat } \cdot \text { an/ } n \text { proses, cara, } \\
\text { perbuatan menyekat }(i) \text {. }\end{array}$ & $\begin{array}{l}\text { Closure or conversion of traffic } \\
\text { flow in order to reduce the COVID- } \\
19 \text { infection rate }\end{array}$ \\
\hline 10. & Mengidikasikan & Indicate & $\begin{array}{l}\text { Mengindikasikan/meng.in.di.ka.si.kan/v memberi } \\
\text { tanda; memberi petunjuk; mengisyaratkan. }\end{array}$ & $\begin{array}{l}\text { Certain indication that confirms } \\
\text { COVID-19 infection }\end{array}$ \\
\hline 11. & Inkubasi & Incubation & $\begin{array}{l}\text { Inkubasi/in } \cdot k u \cdot b a \cdot s i / n \text { masa dari saat penyebab } \\
\text { penyakit masuk ke dalam tubuh (saat penularan) } \\
\text { sampai ke saat timbulnya penyakit itu; }\end{array}$ & $\begin{array}{l}\text { This context refers to the COVID- } \\
19 . \\
\text { Previously, the term was utilized for } \\
\text { all diseases in Biology. }\end{array}$ \\
\hline 12. & Disinfektan & Disinfection & $\begin{array}{l}\text { Disinfektan/dis·in·fek·tan//disinféktan/n bahan } \\
\text { kimia (seperti lisol, kreolin) yang digunakan untuk } \\
\text { mencegah terjadinya infeksi atau pencemaran oleh } \\
\text { jasad renik; obat luar untuk membasmi kuman } \\
\text { penyakit. }\end{array}$ & $\begin{array}{l}\text { Germ cleansing that refers to the } \\
\text { COVID-19 prevention effort }\end{array}$ \\
\hline 13. & Karantina & Quarantine & $\begin{array}{l}\text { Karantina/ka.ran } \cdot \text { ti.na/ } n \text { tempat penampungan } \\
\text { yang lokasinya terpencil guna mencegah terjadinya } \\
\text { penularan (pengaruh dan sebagainya) penyakit }\end{array}$ & $\begin{array}{l}\text { It refers to certain hospitals, private } \\
\text { houses, or other similar venues for a } \\
\text { quarantine purpose for patients with } \\
\text { COVID-19. }\end{array}$ \\
\hline 14. & Kestabilan & Stability & $\begin{array}{l}\text { Kestabilan/ke.sta.bil.an/n perihal (yang bersifat) } \\
\text { stabil; keadaan stabil }\end{array}$ & $\begin{array}{l}\text { This context is utilized in the } \\
\text { surveillance of COVID-19 patients, } \\
\text { condition. }\end{array}$ \\
\hline 15 . & Pagebluk & Outbreak & $\begin{array}{l}\text { Pagebluk/pa.geb } \cdot l u k / J w n \text { wabah (penyakit); } \\
\text { epidemi. }\end{array}$ & $\begin{array}{l}\text { It is a borrowing word from } \\
\text { Javanese Language to present a } \\
\text { dramatic effect in describing the } \\
\text { situation of certain epidemic. }\end{array}$ \\
\hline 16. & Malnutrisi & Malnutrition & $\begin{array}{l}\text { Malnutrisi/mal.nut.ri.si/ n Dok malagizi. } \\
\text { Malagizi/ma.la.gi.zi/ n penyakit yang disebabkan } \\
\text { oleh kekurangan gizi, yang biasanya meliputi } \\
\text { beberapa jenis nutrien, seperti protein, } \\
\text { karbohidrat, dan vitamin. }\end{array}$ & $\begin{array}{l}\text { This context refers to the COVID- } \\
19 \text { patients and non-patients. } \\
\text { It is utilized to educate people to } \\
\text { implement healthy living behavior. }\end{array}$ \\
\hline 17. & Isolasi & Isolation & $\begin{array}{l}\text { Isolasi/iso } \cdot \text { la } \cdot \text { si/ } n 1 \text { pemisahan suatu hal dari hal } \\
\text { lain atau usaha untuk memencilkan manusia dari } \\
\text { manusia lain; pengasingan; pe-mencilan; } \\
\text { pengucilan. }\end{array}$ & $\begin{array}{l}\text { The current context of the term } \\
\text { refers to the COVID-19 patients. } \\
\text { Previously, the term was generally } \\
\text { utilized for prisoners and patients in } \\
\text { hospitals. }\end{array}$ \\
\hline 18. & Fluktuasi & Fluctuation & $\begin{array}{l}\text { Fluktuasi/fluk·tu·a.si/n } 1 \text { Ek gejala yang } \\
\text { menunjukkan turun-naiknya harga; keadaan turun- } \\
\text { naik harga dan sebagainya; perubahan (harga } \\
\text { tersebut) karena pengaruh permintaan dan } \\
\text { penawaran; } 2 \text { ketidaktetapan; kegoncangan: }\end{array}$ & $\begin{array}{l}\text { The current context of the term } \\
\text { refers to the number of COVID- } 19 \\
\text { patients, in addition to all matters } \\
\text { related to COVID- } 19 \text {. }\end{array}$ \\
\hline 19. & Logistik & Logistics & $\begin{array}{l}\text { Logistik /lo gis.tik/ n pengadaan, perawatan, } \\
\text { distribusi, dan penyediaan (untuk mengganti) } \\
\text { perlengkapan, perbekalan, dan ketenagaan. }\end{array}$ & $\begin{array}{l}\text { The current context of the term } \\
\text { refers to the food supply and other } \\
\text { social assistances, as part of } \\
\text { COVID- } 19 \text { management policy. }\end{array}$ \\
\hline 20. & Krusial & Crucial & krusial/kru·si.al/ a rumit, sulit sekali. & $\begin{array}{l}\text { The current context of the term } \\
\text { refers to the emphasis of all urgent } \\
\text { matters related to COVID- } 19 \text {. }\end{array}$ \\
\hline
\end{tabular}


Table 3. Borrowing Terms from English Language

\begin{tabular}{lll}
\hline No & Borrowing Terms & \multicolumn{1}{c}{ Lexical Meaning } \\
\hline 1. & Imported case & $\begin{array}{l}\text { Infection of COVID-19 disease due to the mobility of people from foreign countries } \\
\text { Physical distancing effort to prevent COVID-19 disease infection }\end{array}$ \\
3. & $\begin{array}{l}\text { Physical Distancing } \\
\text { Rapid Diagnostic Test }\end{array}$ & $\begin{array}{l}\text { Initial screening effort to identify IgM and IgG antibody which are produced by human's immunity } \\
\text { to prevent COVID-19 disease infection } \\
\text { Tracking effort to identify the regions of COVID-19 disease infection }\end{array}$ \\
4. & Contact Tracking & $\begin{array}{l}\text { Prevention and mitigation } \text { of COVID-19 pandemic by restricting healthy people from visiting } \\
\text { crowded places }\end{array}$ \\
5. & Social Distancing & Medical instrument for body temperature check \\
6. & Thermal Scanner & Liquid or gel to instantly get rid of the pathogen in hands \\
7. & Hand Sanitizer & Face protective equipment made of transparent plastic that resembles a face mask \\
\hline
\end{tabular}

Table 4. Acronyms

\begin{tabular}{|c|c|c|c|c|}
\hline No & Acronym & $\begin{array}{l}\text { Lexical Meaning } \\
\text { Based on The Great } \\
\text { Indonesian } \\
\text { Dictionary (KBBI) }\end{array}$ & $\begin{array}{l}\text { Translation } \\
\text { in English }\end{array}$ & Contextual Meaning \\
\hline 1. & PSBB & $\begin{array}{l}\text { Pembatasan Sosial } \\
\text { Berskala Besar }\end{array}$ & $\begin{array}{l}\text { Large-Scale } \\
\text { Social } \\
\text { Restrictions }\end{array}$ & $\begin{array}{l}\text { According to the Article } 1 \text { of Government Regulation (PP) No. } \\
21 / 2020 \text {, the Large-Scale Social Restrictions (PSBB) is the } \\
\text { restriction for public activities in certain regions which are infected } \\
\text { by the COVID- } 19 \text {. }\end{array}$ \\
\hline 2. & BPSDM & $\begin{array}{l}\text { Badan Pengembangan } \\
\text { Sumber Daya Manusia }\end{array}$ & $\begin{array}{l}\text { Human } \\
\text { Resource } \\
\text { Development } \\
\text { Agency }\end{array}$ & $\begin{array}{l}\text { Based on the first sentence of the } 16^{\text {th }} \text { paragraph, “... he said after } \\
\text { monitoring the independent isolation center at the Human Source } \\
\text { Development Agency (BPSDM) in Cimahi, Tuesday }(5 / 5) . "\end{array}$ \\
\hline & & & & $\begin{array}{l}\text { BPSDM refers to an agency managed by Echelon I that serves to } \\
\text { develop the quality of State Apparatus human resources in Ministry } \\
\text { of Public Works and People's Housing. }\end{array}$ \\
\hline 3. & PSBB & $\begin{array}{l}\text { Pembatasan Sosial } \\
\text { Berskala Besar }\end{array}$ & $\begin{array}{l}\text { Large-Scale } \\
\text { Social } \\
\text { Restrictions }\end{array}$ & $\begin{array}{l}\text { Based on the second sentence of the first paragraph, "West Java } \\
\text { Governor Ridwan Kamil @ ridwankamil mentioned that the Large- } \\
\text { Scale Social Restrictions (PSBB) policy in his region would be } \\
\text { implemented on } 6 \text { May." }\end{array}$ \\
\hline
\end{tabular}

According to the Article 1 of Government Regulation (PP) No. 21/2020, the Large-Scale Social Restrictions (PSBB) is the restriction for public activities in certain regions which are infected by the COVID-19. 4. SIR $\quad \begin{aligned} & \text { Susceptible-Infected- } \\ & \text { Recovered }\end{aligned}$

Polymerase Chain

5. PCR Polymerase
Reaction

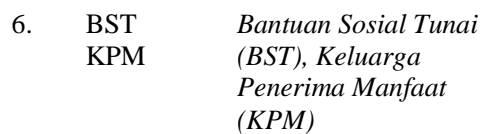

7. PDP Pasien Dalam Pengawasan

8. ODP Orang Dalam Pemantauan

9. OTG Orang Tanpa Gejala
SusceptibleInfectedRecovered

Polymerase

Chain

Reaction

(PCR)

Social Cash Assistance (BST),

Beneficiary

Household (KPM).

Patients under

Treatment

People under Surveillance

Asymptomati c Carriers
Based on the first sentence of the first paragraph, "According to Kompas.com, Singapore of University Technology and Design (SUTD) utilized SIR model on 5 May 2020...”, SusceptibleInfected-Recovered (SIR) is a renowned method for disease infection mapping.

It was due to the limited capacity of Polymerase Chain Reaction (PCR) test to the people who were suspected of being infected. "The total test has yet to reach 10,000 per day, thus we cannot ensure the final laboratory result," said he to SINDOnews, Thursday (07/06/2020).

Bandung, 10 May 2020 - Minister of Social Affairs Juliari Batubara directly supervised the distribution of Social Cash Assistance (BST) 2020 to the Beneficiary Households (KPMs) in Serang Post Office and Cimahi Post Office from 9 to 10 May 2020.

The first sentence of the second paragraph was written, “...The number of Patients under Treatment (PDP) in Surabaya is high despite the decreasing trend."

The second sentence of the second paragraph was written, “...The decreasing trend of the number of People under Surveillance (ODP) occurred in Surabaya and Sidoarjo, in contrast with Gresik," said he

The first sentence of the third paragraph was written, “...According to him, if any PDP, ODP, and OTG are found during the curfew raid, his party will directly perform independent isolation policy in those people's respective houses based on the prevailing requirements or other isolation venues provided by the government."

\section{BBLK

The third paragraph was written, “... Based on the laboratory test from the Center for Health Laboratory (BBLK) of Makassar City, the patient that was referred to Lakipdada Hospital, Toraja was negatively confirmed of being infected." 


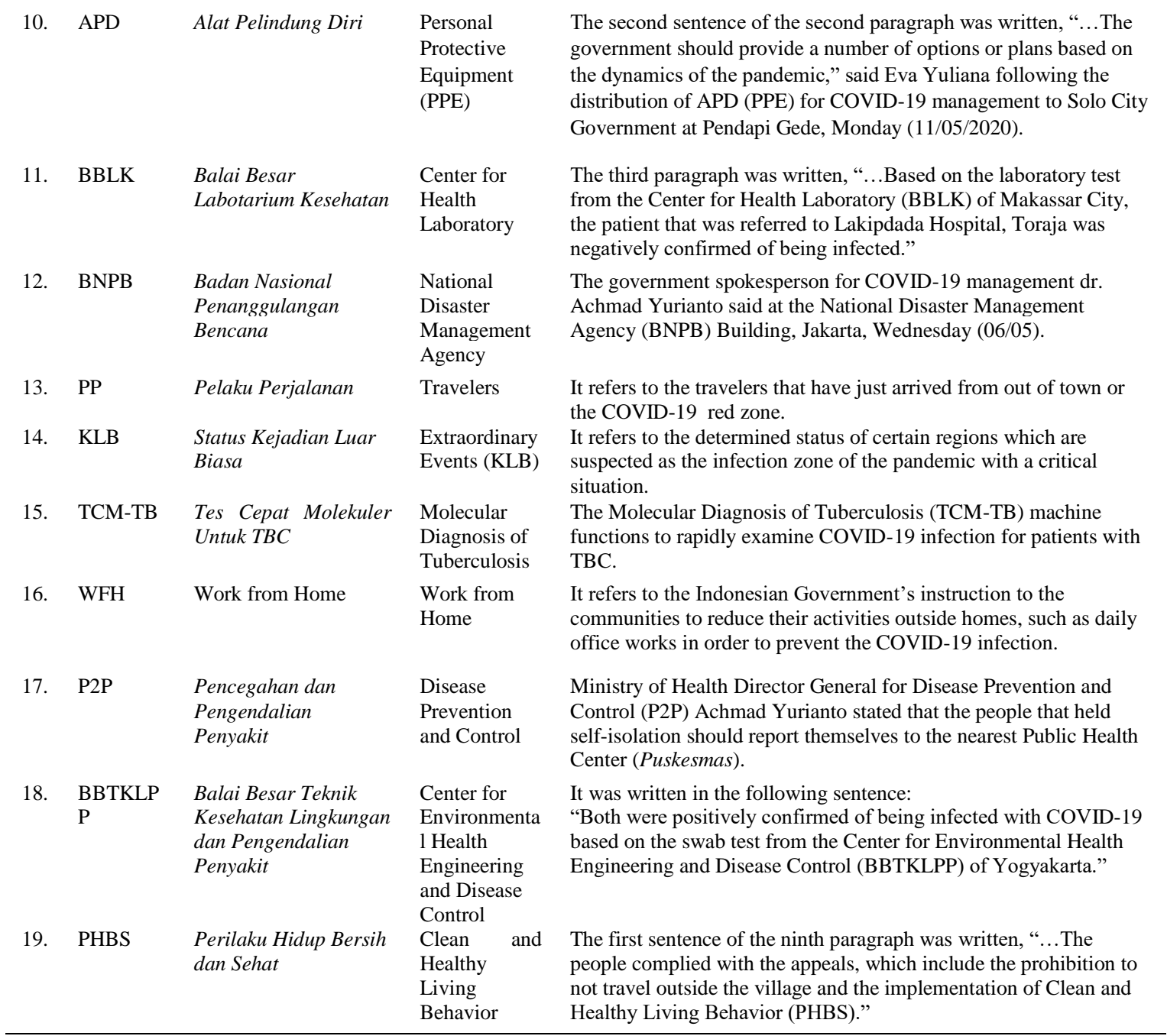

\section{CONClusion}

Based on the findings, we can assume that the current COVID-19 outbreak has affected various aspects of life.The condition has also touched the development of Indonesian Language utilization in its various lingual units, especially with the creation of various terms in the forms of words and abbreviations.

\section{REFERENCES}

[1] B. S. Mózo, "Efek Pemberitaan Media Massa terhadap Persepsi Masyarakat Tentang Virus Corona (Studi Kasus; Masyarakat di Pamekasan)," J. Chem. Inf. Model., vol. 53, no. 9, pp. 1689-1699, 2017.

[2] J. A. Dani \& Y. Mediantara, "COVID-19 Dan Perubahan Komunikasi Sosial," Persepsi, vol. 3, no. 1, pp. 94-102, 2020.

[3] Mubasyaroh, Melawan Hoax di Media Sosial dan Media Massa. Yogyakarta:
Trusmedia Publishing, 2017

[4] B. Yanti, H. Priyanto, \& T. Zulfikar, "Sosialisasi Waspada Infeksi Corona Viru Pada Lansia di Panti Jompo Rumoh Seujahtra," vol. 3, pp. 67-72, 2020.

[5] A. Susilo, et al., "Coronavirus Disease 2019: Tinjauan Literatur Terkini Coronavirus Disease 2019: Review of Current Literatures," J. Penyakit Dalam Indones., vol. 7, no. 1, pp. 45-67, 2020.

[6] E. M. Hasibuan \& M. Yusram, "Hukum Salat Berjemaah Di Masjid Dengan Saf Terpisah Karena Wabah COVID-19," Bid. Huk. Islam, vol. 1, no. 2, pp. 106-124, 2020.

[7] S. Shabrina, "Memperkuat Kesadaran Bela Negara Di Tengah Pandemi COVID-19 (Strengthening the Awareness to Defend the Country in the Middle of the COVID-19)," SSRN Electron. J., vol. 19, 2020.

[8] A. Setiawan Rifqi, "Lembar Kegiatan Literasi Saintik untuk Pembelajaran Jarak Jauh Topik Penyakit Coronavirus 2019 (COVID-19)," J. Ilmu Pendidik., vol. 2, no. 
1, pp. 28-37, 2020.

[9] https://republika.co.id/berita/q75wqq383/jadikata-paling-populer-ini-artiemlockdownem.

[10] E. Subroto, Pengantar Studi Semantik dan Pragmatik, Surakarta: Cakrawala Media, 2011.

[11] Sudaryanto, Metode dan Aneka Teknik Analisis Bahasa, First Ed, Yogyakarta: Sanata Dharma University Press, 2015.

[12] D. E. Subroto, Pengantar Metode Linguistik Struktural, First Ed. Surakarta: UNS Press,
1992.

[13] S. Rijal, "Hubungan Makna Akronim dan Kata Pembentuknya pada Acara Indonesia Lawak Klub di Trans 7," Aksara, vol. 27, no. 1, pp. 73-82, 2015.

[14] Y. L. Arisanti, "Penggunaan Akronim dan Singkatan dalam Media Sosial Facebook di Kalangan Remaja SMA Plus MULTAZAM," J. Literasi, vol. 2, no. 2, pp. 104-112, 2018. 